Original Research Paper

\title{
Cooperation in Rural Areas as a Local System Development Opportunity
}

\author{
${ }^{1}$ Emanuele Schimmenti, ${ }^{2}$ Giovanni Battista Collura, ${ }^{1}$ Giuseppina Migliore, \\ ${ }^{1}$ Caterina Patrizia Di Franco, ${ }^{1}$ Antonio Asciuto and ${ }^{1}$ Valeria Borsellino \\ ${ }^{1}$ Department of Agricultural, Food and Forest Sciences, Università degli Studi di Palermo, Palermo, Italy \\ ${ }^{2}$ Graduated in Organic Farming, Università degli Studi di Palermo, Palermo, Italy
}

\author{
Article history \\ Received: 09-11-2017 \\ Revised: 21-11-2017 \\ Accepted: 02-12-2017 \\ Corresponding Author: \\ Valeria Borsellino, \\ Department of Agricultural, \\ Food and Forest Sciences, \\ Università degli Studi di \\ Palermo, Palermo, Italy \\ Email: valeria.borsellino@unipa.it
}

\begin{abstract}
The development of rural areas requires the adoption of technology innovation and market approach strategies without departing from the specific features of local production systems, such as agricultural practices and the wealth of knowledge of operators. It is even better the exploitation of these resources to characterize the competitive positioning of territorial systems. In this framework, the cooperative Rinascita, which works in an internal rural area of Sicily region (Southern Italy), represents an attempt to maintain agricultural activities, traditions and rural culture as well as to promote and contribute to the development of the area by giving value to and promoting, a typical local production: the "pomodoro siccagno". Such type of tomato, not a very remunerative kind of product, is grown in areas where alternative crops are few or not available. The aim of the paper is to investigate, through the empirical analysis of a case study, on the capacity of the agricultural cooperative sector to undertake innovative processes and to activate multiplicative processes of local development. The importance of the cooperative Rinascita is real and outstanding: despite being still quite modest in terms of quantity of processed tomato and turnover, it has allowed the members of the cooperative to process and directly sell their tomato, freeing themselves from commercial intermediaries operating in the area.
\end{abstract}

Keywords: Social Capital, Agricultural Cooperative, Sicily, Tomato, Typical Product, Valorisation

\section{Introduction}

Rural areas have long been involved in substantial financial support from the European Union (EU) to encourage their development and reduce the gap that separates them from the rest of the Community (Marquardt and Pappalardo, 2014). Current handicaps of rural areas, including geographic marginalization, exodus of young people with consequent population aging and erosion of human and social capital, are counterbalanced by the strong acknowledgment of the contribution that rural areas give to the maintenance and improvement of quality of life and cultural identity. Such opportunities can result in development opportunities as far as rural areas are able to innovate their productive offer, associating products and services with local resources, community cultural identities, local tourist attractions and landscaping resources.
The development of rural areas requires the adoption of technology innovation and market approach strategies without departing from the specific features of local production systems, such as agricultural practices and the wealth of knowledge of operators (van der Ploeg, 2006). It is even better the exploitation of these resources to characterize the competitive positioning of territorial systems (Furesi and Madau, 2014).

Economic research has often asked why territories with analogous physical, human and institutional capital show different economic performances. Past research has evidenced that the immaterial resources underlying relationship economics -social capital in particular-can contribute to reducing the socio-economic marginalization of structurally weak rural areas (Benedetto, 2011; Marquardt et al., 2012).

The marginality of rural areas is not only due to unfavourable economic conditions or insufficient resources, but also to a missing link that is manifested
Science

Publications 
in a lack of exploitation of the economic opportunities that social relations can provide, i.e. social capital (Iyer et al., 2005; Wiesinger, 2007). The latter can therefore act as a factor of rural development if adequately supported by suitable tools of governance that regulate the relations between local actors (Baumgartner et al., 2013; Pileček et al., 2013; McShane et al., 2016).

It was observed that the higher the level of social capital the higher the possibility to transfer knowledge to the population gravitating in that territory and to create a dynamic and virtuous environment, that favours the accumulation of knowledge (Casieri et al., 2010; Nardone et al., 2010; Pileček et al., 2013; Furesi and Madau, 2014) with a positive impact on the economic development (Woodhouse, 2006). As a consequence, the social capital acts in companies as a lever to increase productivity and create ever-increasing returnsand in community as a stimulus for a long-term economic and social development (Benedetto, 2011; Baumgartner et al., 2013; Furesi and Madau, 2014).

In the Italian rural areas there is a multitude of agrofood products that, if valorized, can contribute to the above mentioned development.

Nowadays, the consumers show a growing interest in organic products, associating it not only to food safety and bodily welfare (Davies et al., 1995; Zanoli and Naspetti, 2002; Schimmenti et al., 2013; Cristini and Bellini, 2015) but also to less selfish considerations such as the protection of the environment and of the landscape and animal welfare (Migliore et al., 2015) as well as to an appreciation for local products, which are deemed fresher, safer and healthier (Roininen et al., 2006; Darby et al., 2008; Denver and Jensen, 2014). Also, the consumer is influenced in his choices not only by the functional aspects of the commodity (e.g. taste, texture, colour, etc.), but also and increasingly so, by new intangible elements that are strictly linked to the ethical sphere, such as the impact of the productive processes on the environment, the recycling of the packaging materials (environmental sustainability), the consequences on local economic growth (territorial products), the protection of health (food safety), solidarity towards small producers, justiceand the like (Migliore et al., 2015; Cembalo et al., 2012; Cicia et al., 2012).

In the panorama of Sicilian agro-food industry, the cooperative Rinascita (which operates in an internal area of Sicily, Southern Italy) is today a small, promising reality in the field of tomato industry and it also represents an attempt to give value to, and promote, typical local productions. It does this by following, not just in environmental terms, but also in social and economic terms, the recent productive tendencies taken up by many in the agro-food sector (Pretty, 2008; Jones, 2012; Migliore et al., 2015; Borsellino et al., 2016).
Aware of the fears insinuated in the consumers by the food scandals, which have enhanced a growing demand for guarantees, quality and more detailed information on the production processes, the cooperative has focused entrepreneurial attention on the link between nutrition, gastronomy, tradition and biodiversity by means of transforming family production into a semi-industrial production.

The aim of the study was to investigate, through the empirical analysis of a case study, the ability of the cooperative agricultural sector to undertake innovative processes and to activate multiplier processes of local development. To do this, an analysis of the main issues and further potentialities related to the socio-economic valorisation of a traditional local product such as the "pomodoro siccagno" was carried out. This tomato, currently a not very remunerative product and more and more abandoned, needs to be valorised in such areas, in order to avoid the abandonment of land with few alternative crops (wheat, vines, olive trees and fodder crops) and the consequent decline of local population (with a loss of social and human capital), especially of young people.

\section{Methodology}

The case study we have examined is Rinascita cooperative society, the only associative entrepreneurial entity active in the field of tomato industry in the area of Low Madonie mountains between the provinces of Palermo and Caltanissetta (more precisely in the municipalities of Alia, Caltavuturo, Valledolmo, Vallelunga Pratameno e Villalba), which represents one of the most important production areas of "pomodoro siccagno" in Sicily (Figure 1).

In order to show the role of the cooperative in the local productive area in the tomato sector, we first describe its production context using the data of the agricultural census of ISTAT (for the 1982-2010 period), as well as data collected directly by interviewing stakeholders in the public and private sectors selected for their prominence in the productive and commercial activity of our research subject, with reference to the biennium 2015-2016.

After that, we examine the technical and economic data of the cooperative by means of direct interviews to the people in charge of them, to whom we administered a questionnaire we have built on the ground of our past experience of agricultural research in Sicily (Schimmenti et al., 2011; Di Vita et al., 2013; Schimmenti et al., 2014), structured in three sections. The first section concerns general information about the firm (foundation year, location, the plants, land areas, number of members, number of employees, etc.). The second concerns the technical and productive aspects (description of the processing plants, work and production cycles). 


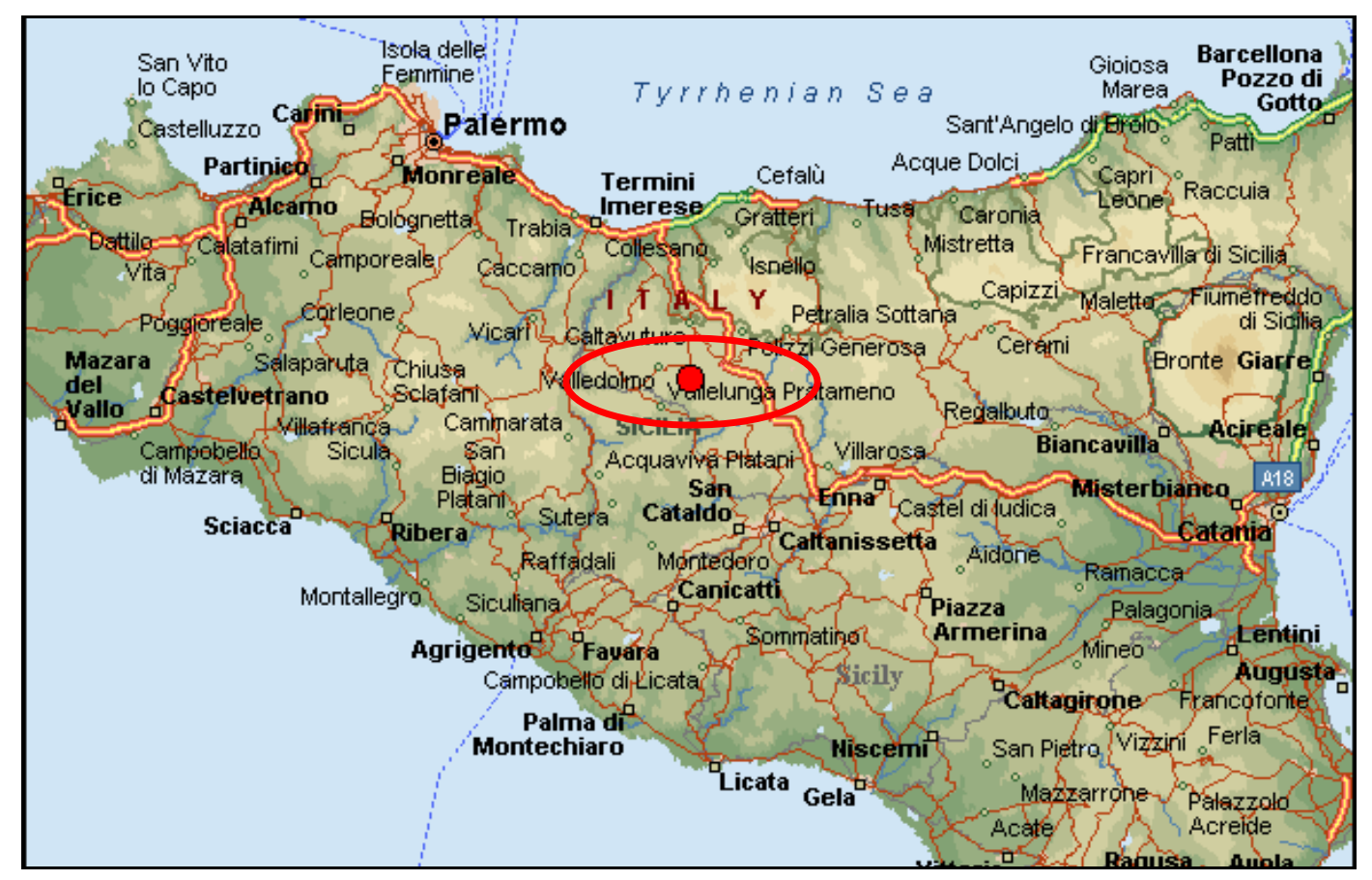

Fig. 1: "Pomodoro siccagno" cultivation area under survey

The third and last part concerns the management and commercial aspects (market-product system, commercial strategy, firm mission, planning, management control) and the activities related to marketing, research, purchase and sales. We have gathered data for a precise period: the 2012-2016 years for the productive and commercial aspects and the year 2016 for socio-structural aspects.

\section{Findings}

\section{The Area}

The territory of the Low Madonie mountains (between the provinces of Palermo and Caltanissetta, in the heart of Sicily) has a wealth of agro-food and cultural heritage. Farmers have always cultivated wheat, tomato, grapevine, olive grove and fodder crops, obtaining quality products, healthy and genuine. More recently, some local producers, privately or in an associative form, equipped themselves with processing and marketing facilities for their own production, thus closing the supply chain and bringing to consumers' tables quality products and specific expressions of the growing area (for example, the historic cellar of Tasca d'Almerita, the Valledoro pastifier, etc.); all this by creating innovative products and services based on both agricultural and natural resources and human skills, had positive socioeconomic effects for the whole territory.

Starting from the 1970s, in the geographical area of our research some cooperatives have begun to operate in the field of the stocking and commercialization of tomato, also by means of contracting with the Sicilian processing industry. At the moment, however, only the cooperative Rinascita is active.

When we look at the data of the last general censuses of agriculture (ISTAT, 1985; 1993; 2002; 2012) for the district we are studying from 1982 to 1990 , we witness a $30 \%$ increase of the area devoted to tomato production (from 481 to 626 hectares). In the following decades we notice instead a decrease (307 hectares in the year 2000 and 227 hectares in 2010). When we turn to another source, SOPAT (Operating Peripherals Sections for Technical Support) No. 56 of Alia, we find that it estimated in the area for the year 2000 a total tomato cultivation of 900 hectares, substantially higher than ISTAT's data.

For the current study and in the presence of official data (ISTAT, 2016) that can be deemed to be underestimated, we operated a territorial survey aimed at identifying where the productive firms are, in order to assess and identify the actual area in which tomato is grown and the average production in the biennium 20152016. The data we collected show that tomato area is about 400 ha (60 ha of which organically farmed), of which 230 ha in the administration of Valledolmo, 90 ha in Caltavuturo, 25 ha in Alia, 10 ha in Vallelunga Pratameno and 45 ha in Villalba. About $60 \%$ of the total area is worked in dry farming (because of the said absence of irrigation reservoirs) with an average yield of about 15 tons/ha and the remaining $40 \%$ is irrigated, with a production of about 70 tons/ha. All tomato production is for industrial and family processing. 
Three farms are mid-sized (about 12 ha each) and around 300 are small firms (with an average size of 1.50 hectares for dry farming and around 1 hectare for irrigated production). Usually the same species is grown on the same land, in many cases with a three-year rotation system: durum wheat, tomato, a leguminous plant.

The farms are found at an altitude ranging from $500 \mathrm{~m}$ to $700 \mathrm{~m}$ above the sea level. Most of them are managed in the form of family farming; that is the agricultural entrepreneur is helped by his family members in growing tomato. The hiring of farmhands is found in few cases only and for specific operations (transplanting and harvesting).

By using the average harvesting results we found, we estimated that in the biennium 2015-2016 the quantity of tomato harvested in the area is on average about 14.8 thousand tons (of which 11.2 thousand from irrigated crops and 3.6 thousand in dry farming), with a value of production at basic prices of around 4.0 million euro.

With regard to commercialization, we noticed that about $60 \%$ of the produce is sold to horticultural traders supplying the consumers of Catania and Messina areas, while $10 \%$ is sold directly to privates who preserve tomato for self-consumption, $5 \%$ is sold at the horticultural wholesale markets of Eastern Sicily, around $5 \%$ is given to the cooperative Rinascita (in the case of "pomodoro siccagno" we witness instead a $20 \%$ figure), $2 / 5$ of which is processed for firms which commercialize the processed produce with their own labels. Plus, we have found 3 mid-size firms (that intercept $18 \%$ of the total supply) that produce with irrigation and sell their tomatoes directly in some regional markets, while the remaining $2 \%$ of the tomato is processed for family consumption by the local population.

So far the various attempts to create a local tomato label have been in vain. The only case of present product valorisation consists in the Slow Food recognition of the "Pomodoro siccagno della valle del Bilìci", which, however, concerns one firm only.

\section{The Case Study}

\section{Structural Aspects}

The cooperative Rinascita was created in 1977 with the juridical form of an Agricultural Limited Liability Cooperative Society, whose purpose was to process the tomato of the cooperative members and commercialize the processed product. Despite some initial efforts made together with other firms - to build a market centre (that never was) to cater the needs of the "pomodoro siccagno" producers of the area, the cooperative, exploiting the Territorial Pacts, only in 2003 was able to build a plant to process tomato and produce preserves to be directly commercialized. The industrial plant itself is composed of a 900 square metres area and of around 3,000 square metres external area (service areas, sheds, warehouses and parking places).
With 30 members ( 3 of whom do not deliver any production to the cooperative) mainly based in the Valledolmo area, the Cooperative has about 45 ha where tomato is grown. There are 23 employees, 22 of whom on short term contracts (for a total in 2016 of 2,222 working days).

\section{Production and Processing}

All the tomato processed by the cooperative is "pomodoro siccagno", grown following the general indications of dry farming, which aims to accumulate as much water as possible in the soil, to impede or reduce the dispersal of such water, to obtain the highest possible water use efficiency.

The cultivation starts with soil tilling (which is ploughed in between August and October in order to help the winter water infiltration) and continues with several harrowings. The planting of seedlings is carried out by the end of April or beginning of May, mainly by using hybrids (Brigade) as well as commercial varieties (Interpeel), with a distance of $1.2 \times 1.8 \mathrm{~m}$. This operation is done by hand and includes a local irrigation to favour the seedlings. There follows an earthing up and several hoeings. Fertilizers and pesticides are those used for organic agriculture. Harvesting (starting at the end of July and ending in mid-October) is carried out manually, more or less every $8 / 10$ days, because the ripening process is progressive, by picking the red fruits and eliminating any fruit presenting colour alteration, necrosis or rotten parts.

The harvest is put in plastic cases containing around $20 \mathrm{Kg}$ of tomatoes and transported to the cooperative's plant, where the technical personnel fill a form in order to certify delivery. Processing is done within 36 hours from harvesting. The following products are obtained: "passata di pomodoro" (tomato puree), "salsa pronta" (ready to use sauce of three types: basil, dill and chili pepper), "pomodoro secco" (dried tomato), "astrattu" (concentrated tomato) and recently also "U siccagnu" (peeled tomato in sauce).

From the exam of productive data of the last five years (Table 1), it is evident that the processed quantities appear in light and steady growth apart from the decrease recorded in 2013. In the meanwhile, the purchased quantities progressively diminished. At the moment of writing, nearly $30 \%$ of processed tomato is certified for organic production.

Table 1: Processed tomatoes produced by cooperative members and external purchase (tons)

\begin{tabular}{lrrrrr}
\hline Processed tomatoes & 2012 & 2013 & 2014 & 2015 & 2016 \\
\hline - from the cooperative & 209.3 & 164.9 & 344.2 & 367.4 & 475.7 \\
members & & & & & \\
- purchased outside & 181.1 & 116.6 & 59.6 & 37.1 & 39.6 \\
Total & 390.4 & 281.5 & 403.8 & 414.5 & 515.3 \\
\hline
\end{tabular}


In the 2012-16 period revenue from tomato has kept constant, remaining, as provided by the contract, at the level of $250 € /$ ton.

\section{Aspects of Commercialization}

The cooperative Rinascita bases itself on a commercial strategy hinged on the favourable reception by the public of quality and organic products, as well as on a complete product line as described earlier, all duly labelled.

Besides retailing, which is done at the plant, a commercial network has been created involving mainly small grocery retailers of various degrees of specialization, who target average/high income consumers, for this is the type for whom local food is important in family nutrition.

The tomato puree is available in two sizes, $410 \mathrm{gr}$. and 680 gr., whose retailing prices are, respectively, $€ 1.50$ and $€ 1.80$; ready to use sauces, available only in the 410 gr. size, sold at $€ 1.80$; dried tomato in oil, in a 200 gr. jar, is sold at the retailer level at $€ 2.50$; vacuum packing instead, destined to restaurants, obtain a $20 € / \mathrm{kg}$ price .

Importantly, a part of the processed tomato is commercialized by one of the main Italian supermarket chains with its own private label.

Considering all of the above, the distribution channels concern privates, wholesalers and large-scale retail. Commercialization takes place almost exclusively in the national territory; over 2012-2016 period sales doubled (Table 2).

Net sale revenue (mainly composed of of processed product sales, but comprising also other items, such as processing for other firms) in the 2008-2016 period shows a steady growing trend, which shows the progressive consolidation and success of the Cooperative
(Figure 2). The firm is concentrating its resources to exploit the opportunities offered by the positive market trend, simultaneously obtaining a better outlet for its production, to shield themselves from the annual price fluctuations. In particular, with regard to the international market, in the absence of commercial partners the Cooperative is seeking to have its production known by participating in International Expos in the agri-food sector (Tuttofood, Cibus, Alimentaria, Expo 2015, etc.). For the home market instead the medium term goal is to become the most representative Sicilian firm for tomato sector.

Finally, the firm's capacity to enhance the market valorisation of its members' production is limited by the quote of the sales values absorbed by all the costs other than those of tomato which remains very high (Table 3 ).

Table 2: Sales in Italy and abroad

\begin{tabular}{ccccccc}
\hline & \multicolumn{2}{c}{ Italy } & \multicolumn{2}{c}{ Abroad } & \multicolumn{2}{c}{ Total } \\
Year & $€$ & $\%$ & $€$ & $\%$ & $€$ & $\%$ \\
\hline 2012 & 321,958 & 98.97 & 3,355 & 1.03 & 325,313 & 100.00 \\
2013 & 468,453 & 99.71 & 1,385 & 0.29 & 469,838 & 100.00 \\
2014 & 492,306 & 96.61 & 17,289 & 3.39 & 509,595 & 100.00 \\
2015 & 567,740 & 94.43 & 33,485 & 5.57 & 601,230 & 100.00 \\
2016 & 625,560 & 95.23 & 31,320 & 4.77 & 656,880 & 100.00 \\
\hline
\end{tabular}

Table 3: Market valorisation of members' production

\begin{tabular}{lllcr}
\hline & \multicolumn{2}{l}{ Net sale revenue } & \multicolumn{2}{c}{ Amount paid to members } \\
Year & $€$ & \% & $€$ & $\%$ \\
\hline 2012 & 358,215 & 100.0 & 52,325 & 14.6 \\
2013 & 547,144 & 100.0 & 41,249 & 7.5 \\
2014 & 612,067 & 100.0 & 86,053 & 14.1 \\
2015 & 695,928 & 100.0 & 110,424 & 15.9 \\
2016 & 813,917 & 100.0 & 146,484 & 18.0 \\
\hline
\end{tabular}

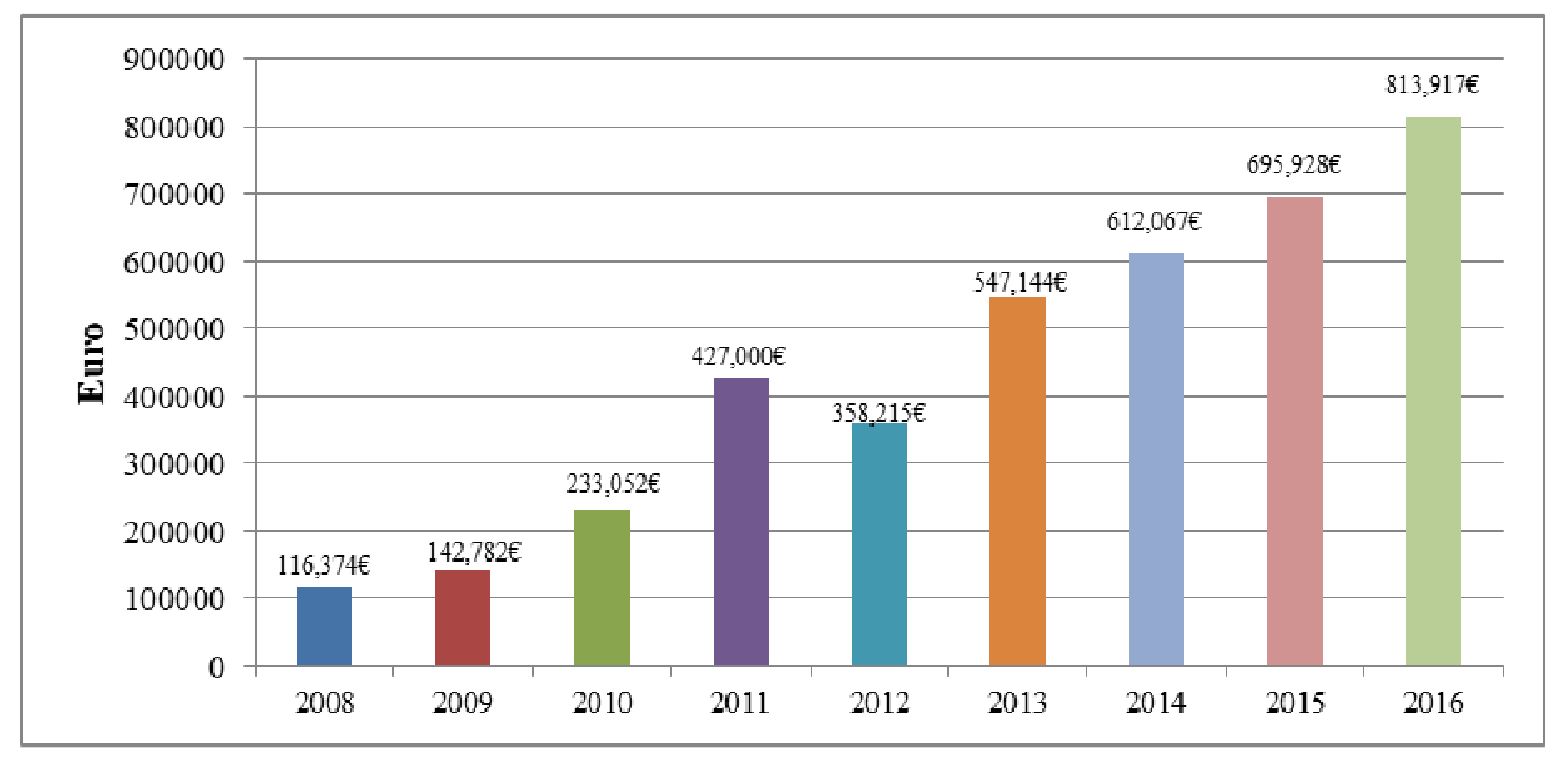

Fig. 2: Net revenue trend 2008-2016 


\section{Conclusion}

There is room in some internal areas of Sicily for the cultivation of the "pomodoro siccagno" to be kept, although the area devoted to it has been decreasing. The case study of the present work -the cooperative Rinascita- operates precisely in such a Sicilian internal area, in which despite a positive trend in terms of area devoted to tomato production in the 1990s we witness a negative trend in the following years (in the biennium 2015-2016 about 400 hectares were estimated, of which 240 in dry farming). Low harvesting yields caused by the particularities of dry farming, narrow seasonality, high production costs (mainly labour cost) and not adequate sale prices have contributed to such tendency. The valorisation of "pomodoro siccagno" itself is inadequate, despite its excellent organoleptic characteristics - being certainly better than the common, irrigated tomato - the cultivation historicity and the traditional productive technique.

The entrepreneurial strategy of cooperative Rinascita has consisted precisely in linking nutrition to the values of tradition and biodiversity by means of evolving family production into a semi-industrial production by creating in 2003 an appropriate plant for processing tomato.

In recent years we witnessed the progressive growth of the cooperative economic performance which, despite being still quite modest in terms of processed tomato quantity and turnover, allowed the few tomato producing members of the cooperative to process and directly sell their tomato, freeing themselves from commercial intermediaries operating in the area. This has produced a great economic value as well as greater self-esteem in the people, who believe in what they have done and want to go on in this direction, processing more and more "pomodoro siccagno" organically farmed, due to its good development perspectives.

The cooperative Rinascita takes part in the current scenario of tomato processing industry by offering a wide and diversified range of products (partly organiccertified), targeting a mid/high income consumer with a favourable perception of typical and local productions, but paying, at the moment of writing, an unprofitable price to members for their tomato production. Besides, the direct sale operated at plant level, a sales network has been created involving mainly more or less specialized small groceries, which cater to a consumer target who openly demands organic products. Also, there has been a recent development in terms of opportunities in some foreign markets. The achievement of economies of scale, together with good market prospects perceived by the cooperative, can promote its further growth, maintaining the traditions and the rural culture as well as the promotion and development of the area. The importance of the Cooperative in the investigated area is real and outstanding, confirming previous studies (Emana, 2009;
Smith, 2011; Melece, 2013; McShane et al., 2016), which asserted that cooperatives are recognized as an important instrument for socio-economic improvement of community. The cooperative Rinascita is a good example of social capital at work as the success of the cooperative relies on trust and reciprocity.

However, some strategic suggestions to improve the management could be an up-grade of the processing plant and also processing higher volumes of "pomodoro siccagno" by increasing the membership base through the incentive of a down payment on produce and a more profitable price.

In conclusion, there are favourable development perspectives for the cooperative and more in general for the "pomodoro siccagno" of the local area which, however, cannot do without adequate valorisation policies (attempted already in the past with scarce success) and marketing policies aiming at spreading knowledge of the peculiar organoleptic characteristics of a local product, obtained in depressed areas with production costs higher than the tomato grown in more favourable environments. This has been stated also in other works on the Sicilian internal areas (Schimmenti et al., 2016, Lanfranchi and Giannetto, 2014; Lanfranchi et al., 2015). The final goal is to make the agricultural exploitation of such areas remunerative, because in recent years there have been growing phenomena of land abandonment as well as of young people emigration with heavy social costs.

\section{Acknowledgement}

The authors are indebted to the cooperative Rinascita for providing data used in this research.

\section{Funding Information}

The authors did not receive any private or public funding to develop the research.

\section{Author's Contributions}

The work is the result of a full collaboration of the authors. However:

Emanuele Schimmenti: Coordinated and set the study, wrote "Methodology" and jointly with Giuseppina Migliore "Introduction".

Giovanni Battista Collura: Drafted "Structural Aspects".

Giuseppina Migliore: Emanuele Schimmenti and Giuseppina Migliore jointly wrote "Introducation".

Caterina Patrizia Di Franco: Antonio Asciuto and Caterina Patrizia Di Franco jointly wrote the paragraph "The Area".

Antonio Asciuto: Antonio Asciuto and Caterina Patrizia Di Franco jointly wrote the paragraph "The Area".

Valeria Borsellino: Wrote "Production and Processing" and "Aspects of Commercialization". 


\section{Ethics}

Authors declare that there is no ethical issues that may arise after the publication of this manuscript.

\section{References}

Baumgartner, D., M. Pütz and I. Seidl, 2013. What kind of entrepreneurship drives regional development in european non-core regions? A literature review on empirical entrepreneurship research. Eur. Planning Studies, 21: 1095-1127.

DOI: 10.1080/09654313.2012.722937

Benedetto, G., 2011. Capitale sociale, capitale umano e sviluppo dei sistemi rurali. [Social capital, human capital and the development of rural systems]. In: Impresa agricola familiare, capitale umano e mercato del lavoro [Family farming, human capital and labor market], Idda, L. and P. Pulina, (Eds), FrancoAngeli, Milan, ISBN: 9788856841510, pp: 269-313.

Borsellino, V., G. Migliore, M. D'Acquisto, C.P. Di Franco and A. Asciuto et al., 2016. 'Green' Wine through a responsible and efficient production: A case study of a sustainable sicilian wine producer. Agriculture Agricultural Science Procedia, 8: 186-192. DOI: 10.1016/j.aaspro.2016.02.092

Casieri, A., C. Nazzaro and L. Roselli, 2010. Trust building and social capital as development policy tools in rural areas. An empirical analysis: The case of the LAG CDNISAT. New Medit., 9: 24-30.

Cembalo, L., G. Migliore and G. Schifani, 2012. Consumers in postmodern society and alternative food networks: The organic food fairs case in Sicily. New Medit, 11: 41-49.

Cicia, G., L. Cembalo, T. Del Giudice and F. Verneau, 2012. Il sistema agroalimentare ed il consumatore postmoderno: nuove sfide per la ricerca e per il mercato [The agro-food system and the postmodern consumer: new challenges for research and market]. Economia Agro-Alimentare, 1: 117-142.

DOI: $10.3280 /$ ECAG2012-001006

Cristini, G. and S. Bellini, 2015. Le dimensioni fiduciarie nell'acquisto dei prodotti biologici: un'analisi esplorativa. Micro Macro Marketing, 24: 21-40. DOI: $10.1431 / 79726$

Darby, K., M.T. Batte, S. Ernst and B. Roe, 2008. Decomposing local: A conjoint analysis of locally produced foods. Am. J. Agricultural Economics, 90: 476-486. DOI: 10.1111/j.1467-8276.2007.01111.x

Davies, A., A.J. Titterington and C. Cochrane, 1995. Who buys organic food? A profile of the purchasers of organic food in Northern Ireland. British Food J., 97: 17-23. DOI: 10.1108/00070709510104303
Denver, S. and J.D. Jensen, 2014. Consumer preferences for organically and locally produced apples. Food Quality Preference, 31: 129-134. DOI: 10.1016/j.foodqual.2013.08.014

Di Vita, G., M. D’Amico and S. Bracco, 2013. Economic performances of small holders PDO viticulture in Eastern Sicily. Quality-Access Success, 14: 99-105.

Emana, B., 2009. Cooperatives: A Path to Economic and Social Empowerment in Ethiopia. International Labour Office (ILO), Dar es Salaam. CoopAFRICA, WP. No. 9. ISBN: 9789221225621.

Furesi, R. and F. Madau, 2014. Capitale umano e sviluppo dei territori rurali: il caso della Sardegna [Human capital and development in rural areas: the case of Sardinia]. In: Competitività dell'impresa e tutela dei lavoratori: obiettivi compatibili in agricoltura? [Enterprise Competitiveness and Workers Protection: Compatible Goals in Agriculture?] Macrì M.C. (Ed.). INEA, Roma: 11-34. ISBN 9788881454419

ISTAT, 1985. $3^{\circ}$ Agricultural General Census 1982 Data. ISTAT, 1993. $4^{\circ}$ Agricultural General Census 1990 Data. ISTAT, 2002. $5^{\circ}$ Agricultural General Census 2000 Data. http://www.istat.it/it/censimentipermanenti/censimentiprecedenti/agricoltura/agricoltura-2000

ISTAT, 2012. 6º Agricultural General Census 2010 Data. http://www.istat.it/it/censimentipermanenti/censimentiprecedenti/agricoltura/agricoltura-2010

ISTAT, 2016. Survey on crops area and production. http://agri.istat.it/sag_is_pdwout/jsp/GerarchieTerr.jsp

Iyer, S., M. Kitson and B. Toh, 2005. Social capital, economic growth and regional development. Regional Studies, 39: 1015-1040.

DOI: $10.1080 / 00343400500327943$

Jones, G.V., 2012. Sustainable vineyard developments worldwide. Oregon University, USA.

Lanfranchi, M. and C. Giannetto, 2014. Sustainable development in rural areas: The new model of social farming. Quality-Access Success, 15: 219-223.

Lanfranchi, M., C. Giannetto, T. Abbate and V. Dimitrova, 2015. Agriculture and the social farm: expression of the multifunctional model of agriculture as a solution to the economic crisis in rural areas. Bulgarian J. Agricultural Sci., 21: 711-718.

Marquardt, D. and G. Pappalardo, 2014. Overcoming challenges of evaluating integrated endogenous rural development and partnership interventions. A worthwhile exercise. Landbauforsch Appl. Agric Forestry Res., 64: 179-194. DOI: 10.3220/LBF_2014_179-194

Marquardt, D., J. Möllers and G. Buchenrieder, 2012. Social networks and rural development: LEADER in Romania. Sociologia Ruralis, 52: 398-431. DOI: $10.1111 /$ j.1467-9523.2012.00571.x 
McShane, C.J., J. Turnour, M. Thompson, A. Dale and B. Prideaux, 2016. Connections: The contribution of social capital to regional development, Rural Society. DOI: 10.1080/10371656.2016.1194326

Melece, L., 2013. Agricultural cooperatives for social capital development in Latvia. Management Organizations: Systematic Res., 66: 53-67. DOI: 10.7220/MOSR.1392.1142.2013.66.4

Migliore, G., M. Di Gesaro, V. Borsellino, A. Asciuto and E. Schimmenti, 2015. Understanding consumer demand for sustainable beef production in rural communities. Quality-Access Success, 16: 75-79.

Nardone, G., R. Sisto and A. Lopolito, 2010. Social capital in the LEADER initiative: A methodological approach. J. Rural Studies, 26: 63-72. DOI: 10.1016/j.jrurstud.2009.09.001

Pileček, J., P. Chromý and V. Jančák, 2013. Social Capital and Local Socio-economic Development: The Case of Czech Peripheries. Tijdschr Econ Soc Geogr, 104: 604-620. DOI: 10.1111/tesg.12053

Pretty, J., 2008. Agricultural sustainability: Concepts, principles and evidence. Philosophical Transactions Royal Society London B: Biological Sciences, 363: 447-465. DOI: 10.1098/rstb.2007.2163

Roininen, K., A. Arvola and L. Lähteenmäki, 2006. Exploring consumers' perceptions of local food with two different qualitative techniques: Laddering and word association. Food Quality Preference, 17: 20-30. DOI: 10.1016/j.foodqual.2005.04.012

Schimmenti, E., A. Galati, V. Borsellino and D. Siggia, 2011 Lo scenario economico dell'ortofrutticoltura in Sicilia [The economic scenario of fruit and vegetables in Sicily]. FrancoAngeli, Milano.

Schimmenti, E., A. Galati, V. Borsellino, C. Ievoli and C. Lupi et al., 2013. Behaviour of consumers of conventional and organic flowers and ornamental plants in Italy. Horticultural Sci., 40: 162-171.
Schimmenti, E., G. Daddi, A. Asciuto, V. Borsellino and C.P. Di Franco et al., 2016. Agriculture in a Sicilian Inland Area: Strategies and motivations of conversion towards multifunctional activities. Quality-Access Success, 17: 87-92.

Schimmenti, E., V. Borsellino, A. Asciuto, M. D'Acquisto and M. Di Gesaro et al., 2014. The Success Factors of a Sicilian Market-Oriented Wine Cooperative. In: The Future of Entrepreneurship, Euromed press, ISBN: 978-9963-711-27-7, pp: 1407-1421.

Smith, S.M., 2011. Cooperatives 101-An introduction to agricultural cooperatives and the federal regulations and Legal Concerns that Impact them.

van der Ploeg, J.D., 2006. Oltre la modernizzazione. Processi di sviluppo rurale in Europa [Beyond modernization. Rural development processes in Europe], Rubbettino, Catanzaro, ISBN: 9788849816099, pp: 148.

Wiesinger, G., 2007. The importance of social capital in rural development, networking and decision-making in rural areas. J. Alpine Research| Revue De Géographie Alpine. http://rga.revues.org/354

Woodhouse, A., 2006. Social capital and economic development in regional Australia: A case study. J. Rural Studies, 22: 83-94.

DOI: $10.1016 /$ j.jrurstud.2005.07.003

Zanoli, R. and S. Naspetti, 2002. Consumer motivations in the purchase of organic food: A means-end approach. British Food J., 104: 643-653. DOI: $10.1108 / 00070700210425930$ 